\title{
Everyday literacy practices: Normalising the school literate child
}

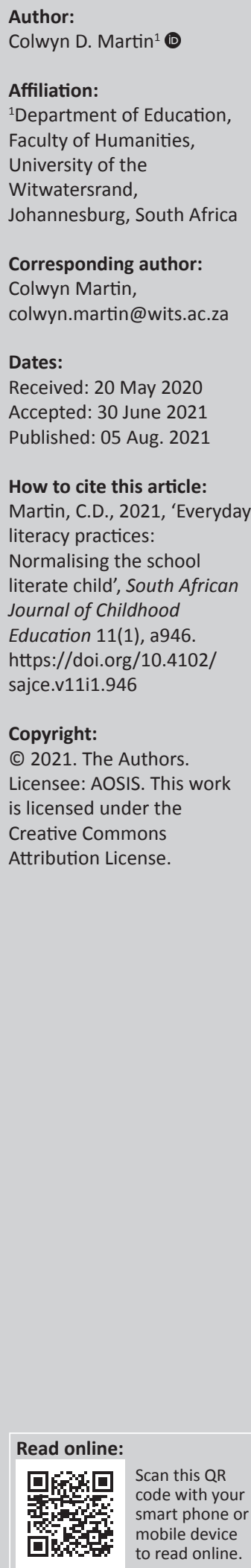

Background: One can argue that literacy practices work to produce forms of literacy knowledge and literate children in early childhood contexts. However, one needs to interrogate how these literacy practices create technologies of power that construct and normalise the school ready literate child.

Aim: The ethnographic study employed in this article explored everyday literacy practices in early childhood contexts that were considered 'usual', the kinds of literate children these practices engendered and its normalising effects on children and teachers.

Settings: The study was conducted in two early childhood centres with two early childhood teachers and teaching children between the ages of 3 and 4 .

Methods: The study was qualitative in nature and used participant observation. A genealogical analysis of literacy practices showed how technologies of power were embodied in different literacy practices that worked to construct and normalise the school ready child in different ways.

Results: The findings revealed that everyday literacy practices were used to produce a literate child through disciplinary processes of observation, normalisation and examination. These literacy practices operated in covert ways where school readiness was tied to educational success. However, during this process of normalisation, children began to [re]position themselves within the literacy space, showing individual agency and self-regulation.

Conclusion: Although the findings of this study are not generalisable, it has implications for how literacy and literacy practices are conceptualised in early childhood settings. This article advocates a reconceptualisation of school readiness by questioning embedded practices within the competence model of school readiness and calls for the early childhood field to dissect incisively what and who are advantaged and disadvantaged through early literacy practices.

Keywords: early childhood; literacy practices; disciplinary power; genealogy; normalisation; agency; self-regulation.

\section{Introduction}

As early childhood care and education (ECCE) policy and reform initiatives begin to gain importance and momentum in South Africa, one questions how these initiatives construct and normalise the school ready literate child. School readiness, growth, child development, lifelong learning and desired results are mantras that permeate policy documents and reform initiatives (Department of Basic Education 2001, 2009, 2012, 2014, 2015). Accompanying these reform initiatives are programmes and practices that constitute best literacy practices that complement the early childhood curriculum and effectively prepare children for formal schooling. These efforts appear rational - early intervention in children's lives enhances their knowledge, skills and behaviours that later lead to academic and economic success (Brown 2017). A clear example of this is the claims that South African ECCE policymakers make that early childhood interventions can reduce poverty, mitigate social problems, prepare young children for formal schooling and later (as adults) enable them to become active participants in the global economy (Atmore 2018). However, the question that needs to be asked is: how do these reform initiatives play itself out in teachers early literacy practices? This article investigates the ways in which ECCE teachers' literacy practices work to produce the literate child. It questions what it means to be literate in early childhood education by tracing how disciplinary power operates through everyday routinised literacy practices. It attempts to show how children begin to reposition themselves

Note: Special Collection: Early Childhood Development in Theory and Practice. 
within the literacy space pointing to the productive effects of disciplinary power. Foucault's (1977) construct of discipline is central to this study and shows how literacy (as a disciplinary body of knowledge) and its ensuing literacy practices (as a mechanism of social control) was used to discipline the school ready child. Viewing literacy practices in this way is under researched in South Africa and there is a paucity of research that uses a Foucauldian lens to explore how teachers' literacy practices construct the school literate child (Dixon 2011) and the different positions that children take up in these relations of power.

\section{Teachers early literacy practices}

Early childhood teachers' literacy practices are pivoted on understandings of what constitutes literacy. As argued by Street (1984) in his seminal work, Literacy Theory and Practice, literacy practices have meanings, intentions and actions and are related to broader social and cultural models. There are two competing views of early literacy practices within early childhood education. The first view is grounded in cognitive psychology and assumes that literacy development occurs in linear, sequential steps and children need to be taught specific skills at specific ages through individual, repeated training (Larson \& Marsh 2015). Specific skills such as 'soundsymbol correspondence, phonemic awareness, understanding of decontextualised language, familiarity with print and conceptual development' are examples of some of the skills that children need to be taught (Flewitt \& Clark 2020:449). Once these knowledge, skills and understandings are in place, it becomes easy to normalise the literacy development of the school ready child. The second view, influenced by sociocultural theories of learning, the social practices approach, argues that whilst decoding skills, meaning building and immersion in print rich environments are important, these skills alone cannot be construed as literacy (Abdulatief et al. 2018:5). Sociocultural research evidenced that early literacy is interwoven into the daily lifeworld of children where they use a variety of symbols systems in different contexts and engage and use literacy in meaningful ways (Gillen, Flewitt \& Sandberg 2020; Street 1984). In contrast to the cognitive view, this approach sees literacy not as linear and unidirectional but rather as instances of agentic behaviours and complex meaning making in real world contexts. Agentic behaviour foregrounds children as rational, competent beings who shape their childhood experiences in the conditions available to them (eds. James \& Prout 2015). As such, children use different strategies to be influential in their daily lifeworld.

Viewing literacy as a process that is embedded in the daily lifeworld of children is in stark contrast to the current political focus in many early childhood settings. South African researchers claim that the cognitive approach to literacy practices is often tied to school readiness and is influential in many early literacy settings (see Chetty 2019; Dixon 2011; Excell \& Linington 2011; Fleisch \& Dixon 2019; Martin \& Ebrahim 2016; Prinsloo \& Stein 2004). They argue that this approach has several limitations: it does not consider the complexities of early literacy development, the diversity of children's motivations to learn and the diverse literacy practices that children encounter in different social and cultural contexts. Additionally, what is noticeable is the failure of the skills-based approach to impact positively on the literacy levels of young children. South African children continue to perform poorly in international, regional and local literacy assessments (Motilal 2021).

Notwithstanding, framing ECCE as an instrument for school readiness has become a universal feature for literacy practices, both in South Africa and internationally (Brown 2015; Brown, Barry \& Ku 2021; Lemphane \& Prinsloo 2014; Martin \& Ebrahim 2016; Moss 2019; Sims et al. 2018). Within the South African context, an example of this is the National Early Learning Development Standards (NELDS), a curriculum related policy initiative which focuses on the educational needs of children from birth-to- 4 year of age and contains validated age-specific indicators focusing on what children should know and be able to do within a specific developmental domain (Department of Basic Education 2009). Martin and Ebrahim (2016) contend that the NELDS can be seen as a tool to advance the neoliberal discourse of school readiness, as well as monitor and evaluate the progress of children on a national scale.

Additionally, there is an implicit formulation of what constitutes quality literacy practices in ECCE policy:

The early years of a child are critical for the acquisition of concepts, skills and attitudes that lay the foundations for lifelong learning. These include the acquisition of language, perceptual/ motor skills required for learning to read and write, basic numeracy concepts and skills, problem-solving skills, and a love for learning. With quality early childhood provision, education efficiency would improve, as children would acquire the basic concepts, skills and attitudes required for successful learning and development prior to or shortly after entering the system. (Department of Basic Education 2014)

This perception reveals a blinkered version of literacy which privileges school literacies and particular kinds of literacy practices. The 'acquisition of language, perceptual/motor skills required for learning to read and write' points to a particular construction of literacy, where literacy is defined as a set of discrete and autonomous skills which can be implemented if children first acquire language, perceptual/ motor skills' as these 'basic concepts, skills and attitudes are needed for school success and lifelong learning'. Basic literacy training privileges and authorises literacy practices that shape what is counted as literacy, and brings into effect the school ready literate child (Martin \& Ebrahim 2016).

Whilst there is evidence that the teaching of pre-literacy skills is important for later literacy development, the concern is that ECCE literacy programmes seem to be moving away from the original supporting goals of promoting children's rights, needs and participation in quality ECCE provisioning (Rudolph, Millei \& Alasuutari 2019). The focus appears to be on teaching a specific set of knowledge and skills, implying a 
single and linear standard of development and learning. Such a parochial framing of readiness, where formal schooling is outmanoeuvring early education and care, creates a situation which sidesteps the current truths about how children develop, and discounts aspects such as young children's positioning as social actors, issues of diversity and socially situated literacy practices.

Additionally, these neoliberal discourses have a debilitating effect on the ECCE sector with its focus on a 'push-down curriculum from formal schooling and standardisation of learning opportunities and positioning of children as investments for future economic productivity' (Sims et al. 2018:1). Atmore (2018) criticises this narrow understanding of early childhood education that focuses on the young child's performance in meeting rigid developmental outcomes set by regulatory authorities, whilst ignoring other aspects of child growth and development. The consequences of positioning children in terms of school readiness have led to ECCE teachers providing learning environments and learning experiences that mimic formal schooling. Moss (2019) asserts that early childhood settings become places where society can apply powerful human technologies on children to produce predetermined outcomes. As such literacy practices operate as disciplinary technologies measuring and assessing children against the norm of school readiness. Additionally, there are evidence-based arguments that a curriculum that focuses on formal skills in preparation for the next stage of education is misinformed, developmentally inappropriate and potentially damaging (Brown et al. 2021; Moss 2019; Neaum 2016).

\section{Foucault and disciplinary power}

In this article, the operation of disciplinary power (Foucault 1977) was intentionally sought by observing teachers' literacy practices to understand how the school ready literate child was made up and normalised. Foucault (1988) maintains that power can be both productive and transformative in nature, and that whenever power exists, opportunities for resistance also exist. Consequently, the concept of disciplinary power provided a useful framework for understanding how teachers' literacy practices worked to produce the school ready literate child as well as how children begin to [re]produce and [re]constitute themselves within the web of power relations of teachers' literacy practices.

Disciplinary power is a technology of power that connects the triple axes of Foucault's writings: the concept of discourse which works to produce power and knowledge relations; and the constitution of the subject in the dual sense of both agent and object of regimes of truth and the interaction between power and knowledge. Within the context of this study, a regime of truth is a dominant way of thinking and speaking about literacy, literacy practices and who a literate child is. Disciplinary power explains how docile bodies are produced, disciplined and self-regulated whilst simultaneously being normalised and subjectified. Following Foucault, Dixon (2011) argues that disciplinary power is a technique that provides procedures and practices for training the early literate child. Henning (2019) argues that these literacy practices operate as disciplinary technologies that work to produce docile literate bodies that conform to certain expectations of what constitutes literacy. These technologies have been found by researchers working in the field of literacy teaching from different contexts: from home-school literacy connections (Dantas \& Manyak 2011) to primary school literacy in Australia (Luke 2018) to early literacy contexts in South Africa (Dixon 2011; Fleisch \& Dixon 2019). Foucault (1977) identifies three disciplinary mechanisms through which disciplinary power operates: hierarchical observation, normalising judgements and the examination. Early literacy practices can be seen as a site where children are subjected to controlling mechanisms, and in turn begin to discipline themselves into productive, docile bodies: the embodiment of a successful school ready literate child.

\section{Hierarchical observation}

Observation is central to early literacy practices and requires that early childhood teachers must know and care for the child (Palaiologou 2016). However, observation in early years settings can also be construed as a technology of power used to control the behaviour and performance of the child to prepare them for formal schooling. Foucault (1977) maintains that disciplinary power situates individuals in time and space where ongoing observation and surveillance give them visibility. During the day, children are observed and measured in time and space, that is, in every aspect of their work and play. Thus, observation (Foucault 1977):

$[I] \mathrm{s}$ inscribed at the heart of the practice of teaching, not as an additional or adjacent part, but as a mechanism that is inherent to it, and which increases its efficiency. (p. 176)

As such, it is part of the technology of power that allows the ECCE teacher to know everything about the child.

\section{Normalisation}

The disciplinary technology of observation allows for teachers to make normalising judgements about children's literacy learning. The power of normalisation defines the 'normal' by allowing ' a penalty of the norm' to be brought into effect as it 'compares, differentiates, hierarchizes, homogenizes, and excludes' (Foucault 1977:183). The power of normalisation ensures homogeneity and allows for children to be compared, differentiated and fixed according to the norm of school readiness.

\section{The examination}

The examination allows for the combination of observation and normalisation to come into play. Foucault (1977) views the examination as an instrument of power that makes it possible to qualify, to classify and to punish. The ECCE centre can be construed as an apparatus of examination where children's literacy learning is judged, and performance is assessed and measured against the norms of school readiness. The ECCE teachers teach whilst simultaneously 
gaining information about children's literacy performances and readiness for schooling. This information is then used to describe, measure and train to bring about improvement in children's literacy learning (Foucault 1977). In essence, children's literacy learning becomes normalised against the standards of school readiness.

\section{Research design and methods}

The study was qualitative in nature and drew on poststructural conceptions of literacy as a situated practice. Qualitative researchers are specifically interested in studying typical individual perspectives and experiences by developing an understanding of the meanings people place on the events and structure of their lives (Cohen, Manion \& Morrison 2011). This approach enabled a deeper understanding of how literacy practices worked to construct the early literate child. The choice of ethnography as a methodological approach was motivated by the assumption that literacy practices take their meaning from the context of which they are part. Ethnography can be viewed as a kind of 'deep theorising' based on the premise that literacy practices can be understood as realworld practices, situated in and shaped by different actors operating in specific social and cultural contexts (Blommaert \& Dong 2010; Papen 2018). Consequently, the use of ethnography allowed for an understanding of the particularities and complexities of the early literacy context: the 'thisness' of the research context. The 'thisness' of the research context is seen by Thomson (2003:73) as a 'distinctive blend of people, happenings, resources, issues, narratives, truths, knowledges and networks, in and through which the combined effects of power saturated geographies and histories are made known'. The particularities of the early childhood centres (ECCs) and the early childhood teachers form a significant component of the research approach, and in the sections that follow it discusses the 'thisness' of the research.

\section{The study site}

The study was conducted in two ECCE centres located within the greater Bloemfontein metropolitan area. Cohen et al. (2011:156) maintain that a researcher makes judgements about the sample 'based on their typicality or possession of particular characteristics being sought'. The research sites were purposively selected as they were in diverse racial, class, gender and language social contexts. Additionally, the researcher knew the principals at both the centres, and this made gaining access to the centres easier.

The language of learning and teaching was English at both the centres. Cheerful Tots ECC catered for children from affluent and middle-class backgrounds. This centre was representative of the trappings of wealth associated with class positioning with well-trained teachers, large indoor and outdoor learning spaces, as well as being well-resourced. It had also gained the reputation of being a 'good' English medium centre which explained the large influx of upper and middle-class Black children.
Universal ECC was also indicative of social class and race positioning development (Zippin, Sellar \& Hattam 2012), with a mixture of black and coloured ${ }^{1}$ children. Many black people from the nearby township had moved into the area which was previously designated for coloured people. The home language of the coloured children was Afrikaans and black children spoke Sesotho. Whilst the centre was poorly resourced, the ECCE teachers made attempts to create a print-rich literacy learning environment by adorning the walls with charts pertaining to the alphabet and phonetics, numbers, days of the week, seasons and the daily timetable.

\section{The research participants}

The two teachers who participated in the study were female and were teaching children between the ages of 3 and 4 . These two teachers were purposively selected as I had a preexisting professional relationship with them. My personal and professional relationship with the teachers was initially made when I was supervising student teachers at the centres during their teaching practice programme. Dee (pseudonym) was a white, middle-class, English-speaking teacher employed at Cheerful Tots ECC. There were 15 children in the 3-4-year-old setting. She had an honours degree in English and Drama and had 18 years of teaching experience in the field of ECCE.

Shari was a black, Sesotho-speaking teacher and worked at Universal ECC. Shari had attended a 2-week training course offered by the Free State Department of Education. She was in the process of completing a Level 5 early childhood qualification at the local technical and vocational college. Shari had 3 years of teaching experience at the centre. There were 28 children in her group. The two participants proved ideal to study early literacy practices and the various ways in which teachers in quite disparate contexts worked to construct the school ready literate child. Data were collected through observations of teachers' literacy practices over a period of 9 months for 3 days per week. The intention was to 'observe participants in their natural settings, their everyday social settings and their everyday behaviour' (Cohen et al. 2011:465).

Throughout the article, the terms, teachers are used to address the two early childhood participants regardless of their level of qualifications. Whilst policy (Department of Basic Education 2001) makes use of the term practitioner, the ECCE 'teachers' thought of themselves as teachers. Additionally, the children at both centres referred to them as teachers.

\section{Data collection}

Data were collected using ethnographic methods of participant observation. Observations were video recorded and field notes compiled. The video recordings were

1.The Population Registration Act (1950) produced fixed and stable categories for racial categorisation of people. People were classified into racial groups, namely white, coloured, Indian and native (renamed 'Bantu' and later 'black'). 
important as they reflected socio-culturally situated practices embodied in the spatial organisation and layout of the setting, routines, everyday literacy practices and the relationships between teachers and children.

Data were collected over a period of 9 months for 3 days per week. The intention was to 'observe participants in their natural settings, their everyday social settings and their everyday behaviour' (Cohen et al. 2011:465). After every observation session, the video recordings were transcribed and read to identify key literacy practices and routines in each setting.

\section{Data analysis}

Data analysis was influenced by Foucault's genealogical tools of disciplinary power, which enabled a record of the 'history of the present' literacy practices and mapped teachers' literacy practices as they 'appear as events on the stage of historical process' (Foucault 1984:86). Genealogy allowed for an exploration of the conditions of power: how disciplinary power operated through teachers' literacy practices, the systems of relations where power operated and where certain literacy practices were formulated and promoted. Data were analysed in three stages. At each stage of the analysis, questions were asked of the observation data that enabled an in-depth and intricate understandings of the teachers' literacy practices. Such questions related to problematisation where the analysis focused on locating the techniques teachers used to govern and construct the early literate child; locating the history of present-day literacy practices to understand how the past influenced present-day behaviours and practices and finally looking at how normative literacy practices position both the child and the teachers.

'Thinking problematically' allowed for continuous movement between theory and data (Foucault 1977:185). Problematisation allowed for an examination of how literacy practices were constituted at the centres at specific times and under specific circumstances, locating these practices within wider discourses such as school readiness and child development and identifying how literacy practices worked to [re]produce and [re]position the school ready literate child. The analysis of literacy practices and the presentation of the data are structured around everyday literacy practices and routines that were considered 'usual' at the ECCE centres: the early morning ring, small group and whole group teaching. The analysis reduced the data to the following three themes: The early morning ring as a normalising literacy practice; Disciplining the body and mind: small group teaching and Disciplining the body and mind: whole group teaching.

\section{Ethics and issues of trustworthiness}

Because of the participatory nature of ethnographic methods to produce data, key ethical issues were considered. Firstly, permission was sought and granted from the university's Ethics Committee before the commencement of data production. Informed consent was also requested and granted from the ECCs' managers, parents of children at the centres and the early childhood teachers. Participants were informed at the beginning that the researcher would always respect and recognise teachers' self-worth, dignity and teaching endeavours. They were also informed that they were free to withdraw from the study at any stage of the research process without being penalised in any way. Once data were transcribed, these were presented to participants to allow them to authenticate, revise, amend or elaborate on. In this way, power differentials that potentially existed were circumvented, thus concretising the participatory nature of ethnography. Anonymity was ensured using pseudonyms for participants and centres - these were chosen by the teachers themselves. An agreement was reached that the centres would be called by pseudonyms, Cheerful Tots ECC and Universal ECC. The teachers chose to call themselves Teacher Dee and Teacher Shari as they were constructed as 'teacher' by the children at the centres. Member checking using critical friends was also an attempt to ensure that misrepresentation was avoided.

The findings in this study relate to just two ECCE teachers at two ECD settings and the results might be different in other contexts. However, whilst the sample is small, it does provide some insight into how teachers' literacy practices are interrelated with systems of literacy knowledge and disciplinary practices that work together to produce a literate child in different ways.

\section{Findings and discussion}

The analysis below shows evidence of disciplinary technologies, of dualisms of what constituted literacy, the regulation of knowledge, space and bodies and the positioning of children as particular kinds of school ready literate subjects. Three key indoor literacy activities are discussed as they are representative of everyday literacy practices that foreground the construction of the school ready literate child. These include the early morning ring at both centres, small group teaching at Cheerful Tots ECC and whole group teaching at Universal ECC. At Universal ECC, the small early learning space, large numbers and lack of teaching assistants placed challenging demands on Teacher Shari. Teacher Shari had to ensure that she created a learning environment that was conducive to early literacy learning for all children. Whole group teaching was, therefore, a management response to the contextual realities of centrebased provisioning at Universal ECC.

\section{The early morning ring as a normalising literacy practice}

The early morning ring at both centres can be construed as an instrument that was used to normalise children's bodily positions and movements, and this functioned as a warm-up to participation and getting ready for learning. The ECCE teachers employed several strategies that focused on the children's physical aspects, dispositions and attitudes. This 
included controlling the physical and sonic environments. The following excerpts are examples of literacy practices that highlight a normative on task body as silent and still.

The children at Cheerful Tots ECC were sitting on the floor in the carpeted area directly in front of Teacher Dee. Teacher Dee was seated on a chair:

'Everybody look at me! Sit on your bottoms. Sit up straight. Show me you are ready? [Children look at the teachers and then sit up straight]. I speak inside, you speak outside. Can you hear a car outside? (Children respond by saying yes). That's because we are awake, and we are listening. Kian and Jan Hendrik you are not listening! You should be looking at me and not talking to each other.' (teacher Dee)

The children at Universal ECC were seated in their chairs directly in front of Teacher Shari. Teacher Shari was standing in front of them:

'Good morning children [children respond by greeting her back]. Show me your eyes [children point to their eyes]. Show me your ears [children point to their ears]. Show me your mouth [children point to their mouths]. Now all of you look at me ... you must listen to me and keep your mouths closed. Fagan, look at me! Do not look at your friend. Listen to me! You can talk to your friend when you go outside.' (Shari)

The above literacy event is an example of how children's bodies were arranged into the correct school ready, literate bodily positions through a ' composite set of bodily inscriptions' and through the reading of the children's bodies 'as a surface of the mind' indicative of a psychologically based pedagogy (Luke 2018118-120). Teachers were able to assess children's participation in the lesson by reading and directing their posture movements and visual gazes: Sit on your bottoms, Sit up straight, look at me - all reveal how the disciplinary technology of hierarchical observation and examination allowed teachers to make normalising judgments about children's' participation in the literacy event. This also reveals a particular kind of power-based hierarchical relationship with the teachers in firm control of the teaching and learning relationship. In this relationship, children do not have autonomy as every action is directed and determined by the teachers. Bodily inscriptions such as listening, looking at the teacher, following instructions for example keeping 'your mouths closed' and 'not talking to your friends' are preludes to normalising a school ready literate child. The literacy practices position the teachers as the one who knows and the primary responsibility of the children is to listen and look at the teachers.

When children did not demonstrate appropriate bodily dispositions, their bodies were 'micro-managed to extract value from every moment', allowing the norm to be brought into effect (Bragg 2018:126). Examples include I speak inside, you speak outside; you must listen to me and keep your mouths closed; Listen to me! You can talk to your friend when you go outside. In addition, children unconsciously learnt that the indoor learning space remains the teachers' domain, and the arena for teaching and learning and the outside space is their arena for socialisation and play.
However, children attempted to challenge these restrictive boundaries as depicted in the following excerpt:

'Began her lesson by talking about the days of the week, numbers, colours and shape. Micah was not paying attention. He turned to Ethan and began to nudge him. Ethan nudged him back. They looked at each other, giggled and then quickly turned to check if Teacher Dee was watching them. They continued participating in the lesson but kept on nudging each other. Teacher Dee did not notice what was going on.' (teacher Dee)

The above excerpt reveals that Micah and Ethan had become accustomed to constant observation and examination. They checked to see if Teacher Dee was watching them, participated in the lesson to some degree but continued to nudge one another. This transgression on their part parallels that of observation on the part of the teachers who also subjected the children to observation. The children have learnt that they need to at least demonstrate some semblance of listening (e.g. look at me, listen to me) even though they might not have been listening to what was being said. It also shows how the children who knew they were being observed, displayed resistance by nudging each other and not listening. This form of resistance is an example of how they in turn watch the teachers' reaction to their attempts at displaying individual agency. When she does not do or say anything, they continue to nudge each other thus displaying their own power and agency in this literacy event.

At the end of the morning ring, the teachers at both the centres organised themselves and the children so that the transition from one literacy event to another was smooth and efficient. Throughout this transition, children's behaviours were observed, regulated and supervised as shown in the following extract:

'We are going outside ... line up ... softly like butterflies. Don't push each other or else we will hurt each other.' (teacher Dee)

'Where must your finger be?' (teacher Shari)

'On your mouth.' (Children)

'Stand up straight. Girls line up first, then the boys ... No pushing.' (teacher Shari)

These intense routines and transitions from one activity to another ensured that children were disciplined and normalised into a gentle, quiet and schooled literate body. The formation of lines for children separated by gender is an example of how children were subjected to the teachers' control and compliance to rules. Being silent, not pushing and moving softly like butterflies, can be construed as civilising schooled behaviour where a 'civilised body is a schooled body, one that stays silent, walks in line, keeps its hands to itself' (De Palma, Membiela \& Suarez Pazos 2011:81). Children learn docility and submissiveness, and they discover their place in the ECCE centre through the submission of their bodies. Varvantakis (2016:250) argues that children 'lining up and standing up straight are representative of psychological development ... if bodies are put in order, thoughts are put in order'. Additionally, being 
silent, moving in a particular way and being still were considered important for the training and normalisation of school ready literate children as they are ' preludes to gestural and linguistic imperatives' (Luke 2018:120). Furthermore, the individual subjectivity of the school ready literate child was [re]constructed and [re]produced as a collective subjectivity where the movements, postures and silences were embedded into the child's body and mind in relation to the other children in the group. This was displayed in: We are going outside ... line up. Don't push each other or else we will hurt each other.

\section{Disciplining the body and mind: Small group teaching}

A key literacy pedagogical practice at Cheerful Tots was small group time. Teacher Dee spent 10-15 min a day with small groups of between 2 and 4 children and this formed part of the daily routine. During small group time, she was able to teach and explain a new concept, determine if the child understood the concept and provide support if needed. During small group teaching, the body and mind became a target of control where children's learning was 'manipulated, shaped and trained' to become literate (Foucault 1977:136). Whilst Teacher Dee was busy working with the small group, the two teaching assistants observed and monitored the rest of the children in the outdoor learning space.

Teacher Dee was working with three children at the table. She wanted the children to create a visual representation of birds' eggs in a nest by sticking crushed eggshells onto the eggs in the picture:

'How many eggs can you see? Count with me. [The children count with her]. What shape is the egg? Remember, we did this shape this morning.' (teacher Dee)

'Oval ... it is like a long circle.' (Ethan)

'Very good, Ethan. I want you to put some glue on your picture and then you must stick these things on the picture. What are these things called? [pointing to the egg shells].' (teacher Dee)

'Eggshells. I had eggs in the morning.' (Monica)

'That's nice Monica ... now listen to me! Touch the eggshells. How does it feel? Is it hard or soft?.' (teacher Dee)

'Soft.' (Shannon)

'Feel it again. Do you think it is hard or soft?' (teacher Dee)

'Hard.' (Monica)

'Yes, it is hard, but you can still break it. What colour are the eggshells?.' (teacher Dee)

'White.' (Ethan)

'Very good ... now put some glue on your picture and stick your eggshells on the picture. Shannon, don't go outside of the line. Stick the shells inside the egg.' (teacher Dee)

'It looks nice like this ... see I made butterflies and birds with the shells.' (Shannon)

'No listen to me! Stick the eggshells on the eggs in the nest.' (teacher Dee)

[The children continued to work on their own whilst being observed by the teachers].
The above literacy event is an example of how each stage of learning and development was prioritised hierarchically into discrete steps where the child's individual participation in the literacy event was assessed and ranked according to expectations determined by the teachers. She questioned the children, asked for clarification by probing and then observed what children were doing. Teacher Dee reinforced preliteracy and pre-numeracy concepts of shape, number, colour and texture, thus directing children's literacy learning and development. The regulation of children's individual performances also functioned as a means of individualisation and examination of children in relation to their participation in the literacy event. Teacher Dee directed learning through questioning, directives and information. Her control over learning processes was reinforced in that she already envisaged how she wanted the children to answer as indicated in: feel it again and do you think it is hard or soft?

What is evident is that children's ways of knowing were almost invisible in this literacy event as they were only classified according to knowing if they were able to work within the boundaries of Teacher Dee's outcomes for the lesson. These ritualised practices positioned Teacher Dee as the key transmitter and constructor of knowledge, and the children as recipients of the teacher's knowledge. This is exemplified in the exchange between Monica and Teacher Dee where Monica commented that she had eggs for breakfast, but Teacher Dee cut her off by saying: That's nice Monica...now listen to me. She thus positioned herself as the expert and the only source of support concerning children's academic performance. Hierarchical observation was evident in the repeated commands (count, touch it) and questions (what colour is it, and how many eggs are there? etc.). These initiation-response-evaluation (IRE) sequences (Luke 2018) are examples of how children were trained and shaped to become literate. The literacy practice normalised and constructed what counted as literacy and what a literate child should be able to do, to be legitimated as a school ready literate subject - namely, answering questions and obeying commands as directed by the teachers. However, within this IRE pattern, Monica was able to play the language game by guessing the word hard prompted by Teacher Dee (feel it again, and do you think it is hard or soft?)

One of the ironies of this literacy event is that even though Shannon's output matched Teacher Dee's expected outcomes (namely, sticking the eggshells on the eggs), her ability to use the eggshells to visually construct and represent butterflies and birds was immediately remarked upon (No, listen to me! and stick the eggshells on the eggs in the nest). Shannon was positioned as an unknowing subject and therefore needed to be given directives by Teacher Dee (e.g. stick the eggshells on the eggs in the nest). The children in this literacy event were expected to produce a particular kind of visual product as determined by the teacher. Shannon had taken the thinking aspect of the literacy event seriously by sticking the eggshells into shapes of butterflies and birds. However, her contribution to the construction of knowledge was essentially sidestepped, thereby positioning the teachers as the expert. The 
children in this literacy event assumed that their thinking and ideas behind their drawings were not important, but the appearance and a specific kind of visual product were, and that this constituted significant literacy learning. More importantly, the child's subjectivity as a meaning-maker and co-constructor of knowledge was negated, where the child was constructed and socialised to just doing and being a 'literate learner' rather than being a full member and participant at the early literacy setting.

Additionally, Teacher Dee's practices became normalised based on pre-assumptions of sameness in relation to how children learn and develop. This enabled her to identify individual differences, and measure educational gaps in terms of universal norms of the school ready literate child. Cutting, pasting, answering questions, sticking objects within the line, amongst others, are all normalising pre-literacy skills that Teacher Dee believed children needed to become school ready. Through observation and under the ' classificatory eye' of the teacher, Teacher Dee was able to 'work with' the child to identify differences in understandings, and to ensure that there was no deviation from the norm of school readiness (Foucault 1977:147). Small group work thus functioned as a means of individualising and training children's body and mind under the 'classificatory eye' and normalising judgements of the teachers (Foucault 1977:159).

\section{Disciplining the body and mind: Whole group teaching}

During whole group teaching, Teacher Shari explicitly taught the same concept to the entire group, assigned individual tasks to children at their tables for practice purposes and assessed individual performances. Whole class teaching was thus a highly regulated space where the teacher was able to train, individualise, observe and assess the literate body and mind.

In this literacy event, the children were seated at their tables and Teacher Shari was standing directly in front of them:

'Be quiet and let's pray. Close your eyes, fold your arms. Thank you, God, for this day. Keep us safe always. Amen [children repeated after her]. (teacher Shari)

'Let's sit still ... don't wriggle in your chairs. Look at me and listen. (teacher Shari)

At the outset of the literacy event, children's bodies were arranged into the correct articulation and instantiation of bodily discipline (Luke 2018). Showing readiness to learn by praying, sitting still, looking at the teacher and listening are bodily demonstrations that functioned as prerequisites to learning, showing the intersection of the body and mind. Teacher Shari began the whole group teaching by pointing to a chart on the wall and asking the children to count with her from number 1 to 20. After the children had finished counting, she took out a book based on the number one:

'All of you look at this book. I can see who is not looking at the book. What number can you see?.' (teacher Shari)

'Number 1 [children shout].' (Children)
'Don't shout out! Lift your hands. Lerato, what is this? [pointing to a tomato in the book].' (teacher Shari)

'I see a tomato.' (Lerato)

'That's good. Ezra, how many tomatoes can you see?' (teacher Shari)

'1 tomato.' (Ezra)

'Good boy. Cameron, what colour are the tennis balls? [Cameron looks at the teacher but does not respond]. Josh, what colour are the tennis balls?.' (teacher Shari)

'yellow, yellow, it's yellow. I have that ball at home. Me and my sister ... we play with my ball. [Other children begin shouting out saying that they also have tennis balls at home].' (Josh)

'Okay, listen everyone ... be quiet and pay attention. How many tennis balls can you see?.' (teacher Shari)

'[shout out $]$ One.' (Children)

'Kyle and Alicia, I can see that you are not listening ... stop talking. How will you learn if you don't listen? Ashley, stop looking at your worksheet and pay attention.' (teacher Shari)

[She continued paging through the book and asked different children to count, identify the objects and the colours of the different objects in the book].

The above literacy event shows how Teacher Shari was operating within the normative definition of what constituted literacy which was grounded in the cognitive model of initiation response and evaluation (Luke 2018). In addition, these literacy skills were divorced from children's everyday real-life experiences and excluded children's ways of knowing. This was evident in the way in which Josh and other children's comments about the toys they have in their homes were ignored. Children's participation and co-construction of knowledge were thus restricted, and their participation was limited to that of the hearer and listener.

In this literacy practice, when Cameron did not keep up with the pace of the lesson, she ignored him and instead asked Josh to answer the question. She did not attempt to probe further to ascertain if Cameron understood what she was teaching, nor did she use his everyday knowledge to scaffold his learning to the new knowledge that had to be learnt. This could be because the emphasis in this literacy appeared to focus on children's compliance with different actions aimed at regulating how they answered questions, their body positions, movements and vocalisations. The repetitive nature of the literacy event revealed the procedures for the sequence of operations that children had to perform. They had to identify the object in the picture, identify the colour of the object and finally count the number of objects. This is in keeping with child development discourse where children learn and develop in stages and through repetition (Flewitt \& Clark 2020). Whilst this may represent the child's developmental step towards getting school ready, these procedures can be construed as constructing a docile, literate individual who embodies respect for the positional power of the teacher and the early childhood institution. 
After Teacher Shari had formally taught the concept by using the book as a resource, she modelled the way in which she wanted the children to complete their individual activity:

'Ok boys and girls, look at my worksheet. Pay attention and watch what I am doing. You are going to do the same thing on your worksheet. (She demonstrated the task by joining the dots to form the number 1). When you are writing number 1 , you start from the top of the line to the bottom of the line. Colour in the elephant grey because the elephant is grey. (She then coloured in the picture of the elephant). Now copy what I have done.' (teacher Shari)

Instructional directives (look at my picture, you are going to do the same thing and copy what I have done) position the teacher as the expert and sole authority of this literacy activity. The words, you are going to do the same thing and copy what I have done, are examples of normalisation where children's production of their written text was based on conforming to the standard of Teacher Shari's text. In setting the standard, children's role in this literacy event shifted from hearer and listener to copier of the teacher's demonstrations.

Whilst the children were busy, Teacher Shari walked around and observed what they were doing. She constantly intervened if the children were not performing the task according to her prescriptions. Through observation, normalising judgements and examination of children's work in progress, Teacher Shari positioned herself as the expert, knower and evaluator. The following are examples of this: Lebo, colour in between the lines ... don't go outside of the lines ... look at my worksheet and 'Katlego put your crayon on the top of the number and go straight down'. [She demonstrated by holding Katlego's hand over the crayon and together they formed the number]. Now you do what I did. In addition, she was able to assess and monitor the children's performance according to the norm of school readiness skills of counting, colouring, joining the dots and identifying the numbers. The continuous ' visible, authoritative gaze' of the teachers is to ensure that children are able to accomplish their tasks efficiently within a specific period of time (Foucault 1977:173).

Whilst children were constantly observed, Teacher Shari was also subjected to surveillance and constant supervision from the principal and parents of the children at the centre. Keeping records of children's performance in the form of children's books and worksheets was used as a disciplinary technology, which enabled the principal and parents to monitor and regulate the work of the teachers. Teacher Shari said: When we have parent meetings, we show the parents what their children can do. The principal also checks our lesson plans and the children's books. The children's books, worksheets and the lesson plans highlight the 'power of writing as an essential mechanism of power' where the subjectivity of the literacy teachers and the school ready literate subject is captured and fixed onto a page (Foucault 1977:189). These artefacts contained all the information that was considered important to the teachers, the centre principal and parents; hence, children's performances were under constant observation and therefore assessable. In addition, the documentation of the teachers' and children's work guaranteed that these records were easily available to those who needed them, including parents and the principal at the centre.

\section{Concluding remarks}

The excerpts presented in this article provided evidence that teachers' literacy practices were used as disciplinary technologies to [re]construct the school ready literate child. Within these early childhood contexts, children were observed, regulated and normalised into becoming school ready. With school readiness as a benchmark indicator for the development of the school ready literate child, hierarchical observation, normalising judgements and examination thus became a normalising literacy practice. During the early morning ring, children's body posture and movement were organised to get them ready for learning by sitting still, looking at the teachers and demonstrating some semblance of participating in the lesson. The small group and whole group activities became the space where learning and development were hierarchised into small steps, and children's participation was either qualified or disqualified based on the teachers' expectations of what was considered a school literate child. As a result, literacy practices were reduced to teaching skills that were required for children to become school ready. In doing so, children's individual agency and meaning making were silenced. However, during this process of normalisation, children also began to regulate themselves, the teachers and their peers by managing their participation in collective and individual activities, in addition to managing their own regulation, thus displaying their individual agency. Within this complex early literacy space, children are learning to relate to one another, their teachers, as well as expectations associated with different literacy practices and routines. Kervin, Comber and Baroutsis (2019) argue that this requires significant discipline as children learn how to regulate their bodies and their learning as well as try to attend to what is important in their teachers speak, read or draw. This has important implications for how literacy and children are conceptualised in practice: are children seen as meaningmakers with capacity and agency or in terms of what are they to become in terms of school readiness.

The aim of this article was to explore ECCE teachers' literacy practices and to gain insights into how the literate child was produced. The intention is not to critique or pass judgement on the ECCE teachers who were observed in the study but rather to gain insights into what it means to be literate in early childhood settings. Taking cognisance of this situation, a reconceptualisation of the readiness processes should consider, via authentic evidence, what in reality prepares all children for learning (Brown 2017). It is important to recognise that children enter ECCE settings with a range of resources from their families to communities which have not previously been acknowledged as valuable and effective (Flewitt \& Clark 2020). According to Manyak and Dantas (2011), these resources should be incorporated into early literacy practices rather than being replaced with school literacy instruction. Hence, we need to question embedded practices within the 
competence model of school readiness so that we do not create new doxa (Kalliala 2014) but rather dissect incisively what and who are advantaged and disadvantaged through ECCE teachers' literacy practices. Perhaps, literacy practices that consider the kinds of literacy knowledge that children bring to the ECCE setting together with the ways in which children learn, in combination with the cognitive approach to early literacy might be a starting point.

\section{Acknowledgements Competing interests}

The author declares that she has no financial or personal relationship(s) that may have inappropriately influenced her in writing this article.

\section{Author's contributions}

C.D.M. is the sole author of this research article.

\section{Ethical considerations}

Ethical approval to conduct the study was obtained from the University of the Free State (Ethical Clearance Number: UFSEDU 2011-0057).

\section{Funding information}

This research received no specific grant from any funding agency in the public, commercial or not for profit sectors.

\section{Data availability}

Data sharing is not applicable as no new data were created or analysed in this study.

\section{Disclaimer}

The views and opinions expressed in this article are those of the author and do not necessarily reflect the official policy or position of any affiliated agency of the author.

\section{References}

Abdulatief, S., Guzula, X., Kell, C., Lloyd, G., Makoe, P., McKinney, C. \& Tyler, R., 2018 'How are we failing our children?' Reconceptualising language and literacy education, viewed n.d., from http://bua-lit.org.za/wp-content/uploads/2019/02/ bua-lit-FINAL051218-2.pdf

Atmore, E., 2018. 'An interpretive analysis of the early childhood development policy trajectory in post-apartheid South Africa', Unpublished PhD dissertation, Stellenbosch University, Stellenbosch.

Blommaert, J. \& Dong J., 2010, Ethnographic fieldwork: A beginner's guide, Multilingual Matters, Bristol.

Bragg, S., 2018, 'Understanding the effects and technologies of contemporary schooling, in R. Thomson, L. Berriman \& S. Bragg (eds.), Researching everyday
childhoods: Time, technology and documentation, pp. 117-138, Bloomsbury Childhoods: Time,
Press, London.

Brown, C.P., 2015, 'Conforming to reform: Teaching pre-kindergarten in a neoliberal early education system', Journal of Early Childhood Research 13(3), 236-251. https://doi.org/10.1177/1476718X14538602

Brown, C.P., 2017, 'School readiness', in L. Miller, C. Cameron, C. Dalli \& N. Barbou (eds.), The Sage handbook of early childhood policy, pp. 287-302, Sage, London.

Brown, C.P., Barry, D.P. \& Ku, D.H., 2021, 'How education stakeholders made sense of school readiness in and beyond kindergarten', Journal of Research in Childhood Education 35(1), 122-142. https://doi.org/10.1080/02568543.2020.1717688

Chetty, R., 2019, 'Literacy teaching in disadvantaged South African schools', Literacy 53(4), 245-253. https://doi.org/10.1111/lit.12188
Cohen, L., Manion, L., \& Morrison, K., 2011, Research methods in education, Routledge, London.

Dantas, M.L. \& Manyak, P.C., 2011, Home-school connections in a multicultural society: Learning from and with culturally and linguistically diverse families, Routledge.

DePalma, R., Membiela, P. \& Pazos, M.S., 2011, 'Teachers' memories of disciplinary control strategies from their own school days', British Journal of Sociology of Education 32(1), 75-91.

Department of Basic Education (DBE), 2001, Education White Paper 5 on Early Childhood Development: Meeting the Challenges of Early Childhood Development in South Africa, RSA Government Printer, Pretoria.

Department of Basic Education (DBE), 2009, National early learning standards for children from birth to four, RSA Government Printer, Pretoria.

Department of Basic Education (DBE), 2012, A policy and performance review of the National Plan for ECD in South Africa, RSA Government Printer, Pretoria.

Department of Basic Education (DBE), 2014, Education for All 2014: Country progress report, RSA Government Printer, Pretoria.

Department of Basic Education (DBE), 2015, South African national curriculum framework for children from Birth to Four (NCF), RSA Government Printer, Pretoria.

Dixon, K., 2011, Literacy, power and the schooled body: Learning in time and space, Routledge, Abingdon.

Excell, L. \& Linington, V., 2011, 'Taking the debate into action: Does the current Grade $R$ practice in South Africa meet quality requirements?', South African Journal of Childhood Education 8(2), 3-12.

Fleisch, B. \& Dixon, K., 2019, 'Identifying mechanisms of change in the Early Grade Reading Study in South Africa', South African Journal of Education 39(3), 1-12. https://doi.org/10.15700/saje.v39n3a1696

Flewitt, R. \& Clark, A., 2020, 'Porous boundaries: Reconceptualising the home literacy environment as a digitally networked space for 0-3-year-olds', Journal of Early, Childhood Literacy 20(3), 447-471. https://doi.org/10.1177/1468798420938116

Foucault, M., 1977, Discipline and punish: The birth of the prison, Allen Lane, London.

Foucault, M., 1984, 'Nietzsche, genealogy, history', in P Rabinow (ed.), The Foucault reader, pp. 76-100, Penguin, Harmondsworth.

Foucault, M., 1988, 'Technologies of the self (A Seminar with Michael Foucault at the University of Vermont, October 1982)', in L.H. Martin, H. Gutman \& P.H. Hutton (eds.), Technologies of the self: A seminar with Michael Foucault, pp. 19-49, University of Massachusetts Press, Amherst, MA.

Foucault, M., 1994, 'An interview with Michael Foucault', in J.D. Faubion (ed.), Power volume 3, pp. 239-297, The New Press, New York, NY.

Gillen, J., Flewitt, R. \& Sandberg, H., 2020, 'Special issue children under three at home: The place of digital media in their literacy practices', Journal of Early Childhood Literacy 20(3), 441-446. https://doi.org/10.1177/1468798420940456

Henning, L., 2019, Researching Early Childhood Literacy in the Classroom: Literacy as a Social Practice, Routledge.

James, A. \& Prout, A. (eds.), 2015, Constructing and reconstructing childhood: Contemporary issues in the sociological study of childhood, Routledge, London.

Kalliala, M., 2014, 'Toddlers as both more and less competent social actors in Finnish day care centres', Early Years 34(1), 4-17. https://doi.org/10.1080/09575146.201 3.854320

Kervin, L., Comber, B. \& Baroutsis, A., 2019, 'Sociomaterial dimensions of early literacy learning spaces: Moving through classrooms with teacher and children', in $\mathrm{H}$ Hughes, J. Franz \& J. Willi (eds.), School spaces for student wellbeing and learning, pp. 21-38, Springer, Singapore.

Larson, J. \& Marsh, J., 2015, Making literacy real: Theories and practice for teaching and learning, 2nd edn., Sage, London.

Lemphane, P. \& Prinsloo, M., 2014, 'Children's digital literacy practices in unequal South African settings', Journal of Multilingual and Multicultural Development 35(7), 738-753. https://doi.org/10.1080/01434632.2014.908894

Luke, A., 2018, 'The body literate: Discourse and inscription in early literacy training', in A. Luke (ed.), Critical literacy, schooling, and social justice: The selected works of Allan Luke, pp. 100-124, Routledge, New York, NY.

Martin, C.D. \& Ebrahim, H.B., 2016, 'Teachers' discourses of literacy as social practice in advantaged and disadvantaged early childhood contexts', South African Journal of Childhood Education (Special Issue on Early Childhood at the Margins) 6(2) 1-10. https://doi.org/10.4102/sajce.v6i2.454

Motilal, G., 2021, 'Systematic literature review of literacy and reading in South Africa', In F. Maringe (ed.), Systematic reviews of research in basic education in South Africa, pp. 235-256, Sun Press, Cape Town.

Moss, P., 2019, Alternative narratives in early childhood, Routledge, New York, NY.

Neaum, S., 2016, 'School readiness and pedagogies of competence and performance: Theorising the troubled relationship between early years and early years policy', International Journal of Early Years Education 24(3), 1-15. https://doi.org/10.108 $0 / 09669760.2016 .1205970$

Palaiologou, I., 2016, The early years foundation stage: Theory and practice, 3rd edn., Sage, London.

Papen, U., 2018, 'Hymns, prayers and Bible stories: The role of religious literacy practices in children's literacy learning', Ethnography and Education 13(1), 119-134. https://doi.org/10.1080/17457823.2016.1277773

Prinsloo, M. \& Stein, P., 2004, 'What's inside the box? Children's early encounters with literacy in South African classrooms', Perspectives in Education 22(2), 67-84.

Republic of South Africa, 1950, Population Registration Act No. 30, South Africa. Parliament: South Africa. 
Rudolph, N., Millei, Z. \& Alasuutari, M., 2019, 'Data practices and inequality in South African early childhood development policy: Technocratic management versus https://doi.org/10.4102/sajce.v9i1.756

Sims, M., Alexander, E., Nislin, M., Pedey, K., Tausere Tiko, L. \& Sajaniemi, N., 2018, 'Infant and toddler educare: A challenge to neoliberalism', South African Journal of Childhood Education 8(1), 1-8. https://doi.org/10.4102/sajce.v8i1.594

Street, B., 1984, Literacy in theory and practice, Cambridge University Press, Cambridge, MA.
Thomson, P., 2003, Schooling the rustbelt kids: Making the difference in changing times, Allen \& Unwin, Crows Nest.

Varvantakis, C., 2016, 'In line: A photo essay on entering a school in Bangalore', In C. Wulf (ed.), Exploring alterity in a globalized world, pp. 263-276, Routledge, Abingdon. Whitebread.

Zippin, L., Sellar, S. \& Hattam, R., 2012, 'Countering and exceeding capital - A funds of knowledge approach to re-imagining community', Discourse - Studies in the Cultural Politics of Education 33(2), 179-192. https://doi.org/10.1080/01596306. 2012.666074 